УДК 81'25(811.133.1)

ББК 81.2Фр

DOI: https://doi.org/10.17308/lic.2020.2/2836

\title{
ХУДОЖЕСТВЕННЫЙ РЕАЛИКОН КАК КАТЕГОРИЯ ПЕРЕВОДОВЕДЕНИЯ
}

\author{
Н. А. Фененко, С. Ю. Бурякова \\ Воронежский государственный университет
}

\section{ARTISTIC REALIKON AS A CATEGORY OF TRANSLATION STUDIES}

\author{
N. A. Fenenko, S. Yu. Buryakova \\ Voronezh State University
}

\begin{abstract}
Аннотация: в статье анализируется специфика передачи при переводе лингвокультурных реалий (артефактов и ментефактов) на материале повести И. А. Бунина «Суходол» и ее переводов на франиузский язык. Реалии представляют собой одну из эстетических доминант произведений И. А. Бунина и делают произведения русского писателя особенно трудными для перевода. Цель данного исследования - проследить особенности ревербализачии лингвокультурных реалий при переводе. Методологической базой исследования является теория межъязыковой реноминаиии и лингвистическая теория реалии. В процессе исследования использовался метод сопоставительного анализа текста оригинала и перевода. Авторы выдвигают и обосновывают гипотезу о том, что в художественном тексте с высоким уровнем национального колорита реалии образуют в своей совокупности художественный реаликон - единый идейно-эстетический комплекс, отображающий индивидуально-авторскую картину мира писателя. Элементы реаликона имеют полевую структуру, в которой можно выделить ядро и периферию. Наибольшие изменения при переводе претерпевает ядро реаликона, поскольку место в нем сохраняют лишь немногочисленные русские L-реалии, а также некоторые франиузские R-реалии, реноминирующие ключевые кониепты повести. Ближняя периферия образована С-реалиями, передаваемыми при помощи экспликации или сопровождающимися переводческим метатекстом. Дальнюю периферию образуют многочисленные R-реалии, функциональные эквиваленты и гиперонимы, а также C-реалии, передаваемыле с помощью франиузских эквивалентов или путем дословного перевода, что полностью стирает национальный колорит текста оригинала. Таким образом, проведенное исследование позволяет выявить сходства и различия в реаликонах как фрагментах художественных картин мира, отображенных в ИТ и ПТ, а также определить и обосновать количественно и качественно доминирующую стратегию передачи начионального колорита.
\end{abstract}

Ключевые слова: реалия, художественный реаликон, межъязыковая реноминация, ядро/периферия реаликона, стратегия перевода.

\begin{abstract}
: the article attempts to analyze specific features of rendering realia (artifacts and mentefacts) in translation process. The present study is based on I. Bunin's short novel "Dry Valley" and its translations into French. Realia are one of the key aesthetic features of I. A. Bunin oeuvre and seriously complicate translation of his works. The purpose of this study is to analyse the features of reverbalisation of realia in translation. The research was conducted in the framework of the theory of interlanguage renomination and the linguistic theory of realia using the method of comparative analysis of the source and translation texts. The authors put forward and substantiate the hypothesis that in a literary text with a high degree of national color realia are functioning as a system thus forming the artistic realikon, an indivisible aesthetic complex, which is used to display the writer's individual picture of the world. The realikon elements form a field structure with a core and a periphery. The core of the realikon is undergoing the greatest changes, since only a few Russian L-realia, as well as some French $R$-realia that name the key concepts of the novel, retain their place in it. The near periphery is formed by $C$-realia rendered by explication or accompanied by a translator's metatext. The far periphery is formed by numerous $R$-realia,
\end{abstract}

(C) Фененко Н. А., Бурякова С. Ю., 2020

Контент доступен под лицензией Creative Commons Attribution 4.0 License.

The content is available under Creative Commons Attribution 4.0 License. 
functional equivalents and hyperonyms, as well as C-realia, rendered by using French equivalents or via literal translation, which completely erases the national color of the source text. Thus, the study allows to identify similarities and differences in realikons as fragments of artistic pictures of the world reflected in source and translation texts, as well as to determine and justify quantitatively and qualitatively the dominant translation strategy used to render the national color.

Key words: realia, artistic realikon, interlanguage renomination, core/periphery of realikon, translation strategy.

Уже в 20-е гг. ХХ в., когда И. А. Бунин эмигрировал во Францию и его произведения стали переводить на французский язык, французская критика признала его выдающимся стилистом, чьи произведения с трудом поддаются переводу: «Но любой перевод Бунина никогда не сравнится с послевкусием оригинала. Хотя в переводе и можно передать некоторые достоинства стиля выдающегося писателя, он не способен в полной мере воспроизвести язык настолько образный и в то же время точный, что ему нет равных» $[1$, p. 70]. Мысль о том, что именно национальный колорит произведений делает творчество И. А. Бунина привлекательным для французского читателя, высказывали многие французские исследователи. Показательно в этой связи высказывание Ш. Ледре, автора первой франкоязычной монографии о творчестве русского писателя: «мы в самом центре русской души... поскольку Бунин изначально (и возможно, в большей степени) интересует нас как прекрасный художник своей страны и самых секретных глубин славянской души» [2, p. 47]. Творчество писателя, по мнению критика, интересно, в первую очередь изображением простых крестьян, поскольку то, что он в своих рассказах говорит о других классах русского общества, «менее интересно, менее ново, показательно» [Ibid., p. 53].

Тексты И. А. Бунина насыщены маркерами национального колорита на разных уровнях, что представляет значительные трудности при переводе. Французские критики и переводчики отмечали целый ряд подобных культурно-специфичных особенностей. Во-первых, одной из переводческих трудностей они признавали разнообразие функциональных стилей речи, элементы которых И. А. Бунин включает в свои произведения с целью создания образа персонажа или особой атмосферы повествования. О трудности передачи такого рода элементов бунинского стиля говорит, например, переводчик многих произведений автора К. Ошар: «Писатель дает слово простому народу и с удовольствием воссоздает особенности народных говоров. Они с трудом поддаются переводу, в них много необычных сочетаний, игры слов, элементов крестьянской речи» [3, p. 152].

Второй отличительной особенностью бунинской эстетики считается обилие реалий, связанных с бытом конца XIX - начала XX в. Это одна из причин, по которой французские критики неоднократно называ- ли И. А. Бунина прекрасным писателем-реалистом. Так, А. Макин характеризует И. А. Бунина как «сказителя быта» (conteur du byt) [4, p. 41], определяя его эстетику как «социологическую» и «этнографическую» и подчеркивая характерную для писателя «эстетизацию бытовой детали» [Ibid., p. 98].

«Русский фон» создается за счет включенных в текст фольклорных элементов, которые присутствуют в виде точных и неточных, частичных и полных цитат: «...большинство рассказов включают отрывки песен и стихотворений, пословиц и библейских текстов; этот метатекст, появляющийся из прошлого, создает контрапункт как голос прошлого, обращающийся к настоящему...» [5, p. 14]. Они всегда вводятся писателем в определенных эпизодах и несут значительную смысловую нагрузку: «Бунин включил целые стихотворения, которые похожи на старинные мелодии и которые в определенных случаях всплывают в его сознании...» [6, p. 44]. К. Ошар, анализируя интертекстуальные связи некоторых рассказов писателя с народными преданиями и сказками, приходит к следующему выводу: «В своих рассказах Бунин переходит от фольклора к реальности, не искажая подлинности повествования; действия персонажей остаются теми же» [3, p. 330].

Таким образом, для произведений И. А. Бунина характерна высокая степень «укорененности в культуре» [7, p. 86], что делает их непростым материалом для межкультурной трансляции. В доказательство приведем слова М. Парижанина, одного из первых переводчиков, столкнувшихся с этими стилистическими особенностями: «задача переводчика необыкновенно сложна; иногда ужасна. Ни одно слово Бунина, всегда стоящее на своем месте, не должно терять свое значение, должно всегда сохранять налет старины и своеобразное звучание, и ритм, и богатство смысловых оттенков» [8, p. V].

Цель данного исследования - выявить особенности передачи при переводе на французский язык реалий, образующих художественный реаликон произведений И. А. Бунина, а также проследить специфику «реконструкции» структуры и семантики реаликона во французском тексте.

Настоящее исследование проводилось в рамках теории межъязыковой реноминации [9], которая заключается в создании в тексте перевода (ПТ) таких новых номинаций, которые были бы эквивалентны 
номинациям чужих реалий в тексте оригинала (ИТ).

Методологической основой нашего исследования является также лингвистическая теория реалии, согласно которой в процессе анализа выделяются три стороны реалии как особого языкового знака, обозначаемые специальными терминами, которыми мы будем оперировать в данной работе:

- R-реалия - реалия как натурфакт или артефакт, т. е. предмет реальной действительности;

- С-реалия - реалия как идеальный эквивалент среды обитания социума (ментефакт);

- L-реалия как средство номинации культурного концепта [10, с. 10].

Материалом для исследования послужила повесть И. А. Бунина «Суходол» (далее - ИТ) и два ее перевода на французский язык. Первый был выполнен М. Парижаниным в 1923 г. и вошел во второе издание сборника «Чаша жизни» (Le Calice de vie) 1990 г., которое использовано в данном исследовании (далее - ПТ1) [11]; второй принадлежит М. Лежен и датируется 2005 г. (ПТ2) [12]. Всего в ИТ выделено 242 словоупотребления $137 \mathrm{R}$-реалий и 68 словоупотреблений $46 \mathrm{C}$-реалий.

Для повести «Суходол», как показал анализ, характерно употребление всех типов реалий, присущих прозе И. А. Бунина в целом (см. подробнее [13]). В частности, наличие:

- R-реалий-регионализмов (коник, наливашник, хворостик, жбан);

- C-реалий фольклорных единиц: народные песни, пословицы, частушки, прибаутки («Pот до ушей, хоть завязочки пришей»; «Волк коню не свойственник» и др.);

- C-реалий-диалектизмов, передающих фонетические, лексические, грамматические особенности народных говоров и речевой характеристики персонажей крестьянского происхождения («Что ж, - говорит раз барчуку, - ты подрастете, будете меня пороть?»; «Нет, дед, не калянься: видно, уж придется подгузники скидывать! Не минуешь», «Бяда! - бормотал он, задыхаясь. - Бяда...» и т. п.). Включение подобных элементов в ткань повествования признается филологами неотъемлемой чертой бунинской эстетики (см., например, [14] и др.).

Для ИТ характерно выполнение реалиями целого спектра функций помимо номинативной: аллюзивной, символьной, эстетической, сюжетообразующей, использование реалий как средства создания художественного образа. Например, в повести «Суходол» некоторые реалии - предметы одежды (R-реалии) являются знаковыми в рамках задач эстетики данного произведения.

Выделенные реалии образуют в своей совокупности художественный реаликон произведения, пос- кольку функционируют в нем не как отдельные, изолированные единицы, а как единый интенционально-эстетический комплекс, который служит для отображения авторской картины мира: изображения художественной действительности, создания национального, исторического и социального колорита текста. Для обозначения этого идейно-эстетического единства мы используем термин индивидуально-авторский (или художественный) реаликон [15]. Подобно художественному ономастикону, он создает в тексте «особый код», обусловленный, с одной стороны, структурами социокультурного знания, а с другой - жанрово-стилистическими особенностями организации произведения и его композиционно-идейными характеристиками [16, с. 7].

Реаликон художественного произведения имеет системную организацию, обусловленную интенциональностью авторской концептуализации картины мира и, в силу своего системного характера, может рассматриваться как языковое поле, представляющее собой совокупность языковых единиц, «объединенных общностью содержания (иногда также общностью формальных показателей) и отражающих понятийное, предметное или функциональное сходство обозначаемых явлений» $[17$, с. 340$])$.

В структуре художественного реаликона как полевой модели целесообразно различать ядро и периферию (ближнюю и дальнюю). При этом иерархической основой ее организации следует считать «полноту и максимальную интенсивность признаков в центре структуры и их разреженность и ослабление на периферии» [18, с. 51]. Кроме того, важным оказывается и частотный показатель как «один из релевантных критериев встречаемости лексической единицы, выражающей тот или иной концептуальный признак» $[19$, с. 66].

При определении структуры художественного реаликона, представленного в повести «Суходол», мы используем следующие критерии.

1. Степень интенсивности национального признака реалии:

- отсутствие соответствующей номинации в принимающем языке, наличие в нем так называемой лексической лакуны: лапти;

- отсутствие некоторых компонентов денотативного значения номинации реалии в принимающем языке (частичная реалия / лакуна денотативного значения): платок;

- отсутствие коннотативного значения (частичная реалия / лакуна коннотативного значения): юродивыци;

- отсутствие сигнификата (С-реалия/С-лакуна): кланяться в пояс;

- наличие у номинации словарной пометы «рег., обл.»: пунька, поддевка, наливашник. 
2. Частотность употребления реалии в контексте. Наибольшей частотностью характеризуются полные реалии и частичные реалии с лакунизированным для французского языка денотативным компонентом значения. Так, реалия изба имеет 23 употребления, хотя и выполняет чисто номинативную функцию. Аналогично функционирует реалия барчук (11 упоминаний в ИТ).

3. Функция реалии в художественной системе произведения. Реалии играют важную роль для «идеологии художественного произведения», они могут стать ключевым понятием произведения, «основой авторской концептуализации» [20, с. 311], приобретая в нем символьную функцию. Так, суходольская усадьба, чья история прослеживается от расцвета до полного запустения, становится символом упадка, отмирания старого помещичьего уклада жизни. Русская реалия усадьба встречается в ИТ 21 раз и может рассматриваться как одна из семантических доминант текста. Реалия дворня (15 упоминаний в ИТ) имеет следующее значение: «1. Крепостные крестьяне, оторванные от земли и взятые на барский, господский двор. 2. Домашняя прислуга в помещичьем доме» [21]. Оба эти значения актуализируются в ИТ. Важность данной реалии обусловлена тем, что И. А. Бунин стремится показать тесную связь помещиков и крепостных (Сp., например: «Но душа-то и в нем была суходольская, - душа, над которой так безмерно велика власть воспоминаний, власть степи, косного ее быта, той древней семейственности, что воедино сливала и деревню, и дворню, и дом в Суходоле»). Реалия икона (в ИТ используется как в этой форме, так и в виде лексемы образ, в особенности суздальский образ Меркурия как символ рода Хрущевых, и встречается 27 раз. Реалии усадьба, дворня, икона, помимо номинативной, выполняют в повести и символьную функцию, т. е. занимают переходное положение между R- и C-реалиями.

На основе указанных выше критериев можно представить полевую модель художественного реаликона произведения «Суходол»: его ядро составляют наиболее национально окрашенные ЛЕ, называющие традиционные реалии русского быта - R-peaлии, зафиксированные в русско-французских словарях (тематически их можно разделить на несколько групп: предметы одежды: рубаха, ильк, лапти, поддевка, платок и пр.; предметы быта: самовар; хозяйственные постройки и части дома: амбар, гумно, сениьы, горница, рига, баня и др.; средства передвижения: телега, дрожки, розвальни; музыкальные инструменты: балалайка, жалейка; религиозные реалии: угодник, блаженный, ладанка, курительная монашка, кутья и др., реалии с наиболее ярко выраженным национальным компонентом значения - реалии-регионализмы: хворостики, наливашники, ко- ник, пунька и др., наиболее частотные (барчук, изба) и наиболее функционально значимые (усадьба, дворня, икона/образ).

Ближняя периферия образована R-реалиями, которые имеют общенациональный компонент значения, но не зафиксированы русско-французскими словарями: однодворец, суровец, покои, портки, рундук, старчик, обжорный навес, курительная монашка, подпоясок и др. К ближней периферии мы также относим С-реалии, называющие религиозные праздники и посты: Петров день, Петровки, Покров, престольный праздник; С-реалии, обозначающие обычаи и традиции: меняться крестами, кланяться в пояс, целовать в губы три раза в знак приветствия; С-реалии, отсылающие к событиям русской истории: очутиться за Ростовом-Батюшкой, Крымская кампания, слухи о воле, отправить в Сибирь на поселение и др.; С-реалии, воссоздающие особенности народной речи: пословицы и поговорки, фрагменты народных песен, речевая характеристика персонажей; C-реалии - интертекстуальные включения: Баба-Яга, домовой, сказка об аленьком изветочке, «Людмила». Все перечисленные R- и C-peaлии участвуют в создании национального колорита произведения.

Дальнюю периферию образуют немногочисленные «чужие» реалии, например, улус, иаман, хата, махоточка, выиитое полотенце и др.

Рассмотрим основные способы реноминации реалий, входящих в состав реаликона ИТ.

Для анализируемых переводов произведения «Суходол» (ПТ1 и ПТ2) характерен ограниченный перечень используемых «чужих» (русских) L-реалий. Так, в ПТ1 встречаются следующие лексические единицы: isba, moujik, steppe, Tatars, tarantass, samovar, icône, balalaïka, cafetan, tiouria, kvas, télègue, troikk.

Для перевода М. Парижанина характерна интересная особенность: переводчик прибегает к замене одной чужой реалии другой, также чужой, которую, по-видимому, считает более известной читателю первой половины ХХ в. или же более привычной для себя. Например:

ИТ: Он выхолился, пополнел, носил дорогие архалуки (...).

ПТ1: Il se soignait, engraissait, portait de somptueux cafetans (...) [11, p. 188].

В анализируемом примере заимствованная у народов Кавказа реалия архалук, обозначающая короткий кафтан, заменяется реалией cafetan, зафиксированной во французских словарях со следующим значением: Платье, преимущзественно для торжественных случаев, которое раньше носили мужчины на Востоке [22]. (Здесь и далее перевод словарных дефиниций и комментариев наш. $-H$. Ф., С. Б.) 
Для ПТ2 характерен несколько иной набор «чужих» L-реалий, большинство из которых вводится за счет переводческого комментария по типу реноминации «Чужая L-реалия + своя C-реалия». Так, комментируются реалии ПТ2: oulous, kvass, staroste, bartchouk, télègue, knout.

Например:

ИТ: мастерил себе тюрю - неумело толок $и$ растирал в деревянной чашке зеленый лук, крошил туда хлеб, лил густой пеняшийся суровец и сыпал столько крупной серой соли, что тюря оказывалась горькой.

ПТ1: (...) il (...) se cuisinait lui-même du «turu» (ошибка переводчика, связанная с выбором формы косвенного падежа существительного. - Н.Ф., С.Б.); d'une main maladroite il pilait et triturait dans une écuelle de bois des tiges d'oignon, y émiettait du pain, $y$ versait un kvas épais et mousseux et saupoudrait cela d'une telle quantité de gros sel gris que le mets, trop amer, devenait immangeable [11, p. 169].

ПТ2: il (...) se confectionnait une tiouria: il écrasait maladroitement et pilait dans un plat en bois des oignons verts, y émiettait du pain, versait du kvass* d'orge épais et pétillant et mettait tellement de gros sel gris que la tiouria était immangeable [12, p. 42].

*Boisson légèrement pétillante faite avec de l'eau, du pain de seigle grillé et du sucre, que l'on fait fermenter avec de la levure et du houblon.

В обоих ПТ используется «чужая» L-реалия turu, tiouria, поскольку последующий контекст позволяет полностью раскрыть ее значение. Кроме того, для реноминации реалии суровеи, обозначающей особый вид кваса из ржаных отрубей и муки, используют русскую R-реалию - гипероним kvas/kvass d'orge, которая в ПТ2 сопровождается комментарием.

В некоторых случаях переводчики при реноминации чужих R-реалий прибегают к созданию «своей» C-реалии - развернутой номинации, раскрывающей ее сущностные характеристики. Такая C-peалия может создаваться как непосредственно в тексте перевода, так и в переводческом метатексте. Например:

ИТ: Зимой умерла Ольга Кирилловна - и она выпросилась ехать (...) на похоронь, ела там кутью (...)

ПТ1: Pendant l'hiver, Olga Kirillovnamourut, - et Natalie demanda la permission d'accompagner à l'enterrement les vieilles femmes (...); et ellemangeale riz sucré, le mets des funérailles (...) [11, p. 215].

ПТ2: Pendant l'hiver, Olga Kirillovnamourut - elle insista pour aller à l'enterrement (...), elle y mangea de la koutia* [12, p. 107].

*Gâteau béni fait de grains de blé, d'orge ou de riz avec du miel, que l'on mange après un office pour les morts.
В ПТ1 переводчик создает развернутую номинацию, эксплицирующую релевантные для понимания контекста черты реалии: «сладкий рис, поминальное блюдо». В ПТ2 для тех же целей создается «своя» С-реалия в постраничной сноске: «освящуенный пирог, приготовленный из зерен пшеницьы, ячменя или риса с медом, который едят после отпевания умериего».

Однако гораздо чаще переводчики используют способы реноминации, содержащие «свои» R-реалии, которые могут выступать либо функциональным эквивалентом русской реалии, либо являются гиперонимом по отношению к ней. Например:

ИТ: Был он просто пьяница, но играл блаженного.

ПТ1: C'était simplement un ivrogne, mais il jouait le rôle d'imbécile du bon Dieu [11, p. 219].

ПТ2: C'était tout bonnement un ivrogne, mais il jouait au saint [12, p. 113].

В ИТ встречается реалия блаженный в значении «Глуповатый, чудаковатый (первонач. юродивый) (разг.)». Мы рассматриваем данную номинацию как частичную реалию в связи с семантическими и функциональными различиями соответствующих ЛЕ: юродство в западной культурной традиции не имело такого масштаба и значения, как на Руси. Это подтверждает определение этого феномена, предложенное во французской версии энциклопедии Wikipedia в рамках статьи «Fol-en-Christ»: «юродивыц - русская адаптация явления “безумства ради Христа”, особая форма монашества в православной религии. Юродивыци - это человек, который намерено ведет себя так, чтобы казаться другим людям сумасшедшим. Он ведет бродячий образ жизни, ходит частично или полностью обнаженным, не имеет постоянного места жительства, разговаривает загадками и может совершать действия, которые кажутся аморальными» [23].

В обоих ПТ используются функциональные эквиваленты, которые акцентируют разные компоненты значения реалии: в ПТ1 imbécile du bon Dieu (олуx цзаря небесного) очевиден пейоративный оттенок, который присутствует и в ИТ; в ПТ2 saint (святой), лексема в сочетании с глаголом jouer (uграть) передает смысл, но коннотативный компонент нейтрализуется.

Реноминацию русской R-реалии гиперонимом можно проиллюстрировать следующим примером:

ИТ: И сначала все в точности исполнял, посетил даже всех мелкопоместных (...)

ПТ1: Et, eneffet, au début, ils 'acquittaexactement de satâche, visita les plus modestes propriétaires [11, p. 188].

ПТ2: Au début, ilexécuta tout cela avec la plus grande exactitude, ilrenditvisite aux plus petits propriétaires [12, p. 68]. 
Реалия ИТ мелкопоместный имеет следующее значение: «Небогатый, владеющий небольшим участком земли, маленьким поместьем» [24]. Релевантной для ее понимания можно также считать информацию, что такие дворяне имели зачастую 5-6 крепостных (не более 21 крепостного мужского пола) и поступали на государственную или военную службу, чтобы обеспечить дополнительный источник дохода [25]. В обоих ПТ используется гипероним propriétaire - coбственник в сочетании с прилагательными modeste скромный, petit - маленький. Данный способ реноминации позволяет французскому читателю понять содержание фрагмента, однако не вся культурно-специфичная информация остается раскрытой, что, однако, не приводит к образованию текстовой лакуны.

Ср. также:

ИТ: (...) престранную фигуру в халате и шлыке (...)

ПТ1: (...) un grand corps d'étrange aspect, vêtud'une robe de chambre et coiffé d'un capuchon [11, p. 152].

ПТ2: (...) unegrande silhouette trèsétrangeen robe de chambre et en bonnet [12, p. 20].

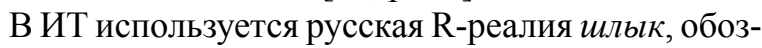
начающая конусовидный головной убор русских крестьянок. В ПТ1 переводчик использует функциональный эквивалент capuchon - капюшон, поскольку далее в тексте говорится, что шлык был «из какой-то грязной тряпки», т. е. основная функция - защита от непогоды. В ПТ2 переводчик выбирает гипероним bonnet - шапка, колпак.

В редких случаях переводчики прибегают к опущению реалии, ср.:

ИТ: (...) горел серебряным треугольником, могильным голубцом Скорпион...

ПТ1: (...) brûlaiten triangle d'argent, encroix de cimetière, la constellation du Scorpion [11, p. 162].

ПТ2: (...) brûlait un triangle argenté d'un gris sépulcral [12, p. 32].

В ИТ русская R-реалия голубец обозначает крест со своего рода крышей наверху, характерный для славян, и используется как элемент тропа, в данном случае, метафоры. В обоих ПТ переводчики опускают данную реалию, сохраняя ассоциацию с кладбищем, могилой: в ПТ1 используется гипероним горело серебряным треугольником, кладбищенским крестом, созвездие Скорпиона; в ПТ2 актуализируется только цветовой компонент: горел серебристый треугольник серый, как гробниц̧а.

Как отмечалось выше, в повести «Суходол» присутствуют C-реалии различного типа, способствующие воссозданию национального и исторического колорита. Их реноминация в обоих ПТ осуществляется тремя способами: созданием своей С-реалии функционального эквивалента, своей С-реалии посредством дословного перевода или опущением С- реалии и экспликации ее содержания непосредственно в ПТ.

Функциональные эквиваленты русских С-реалий создаются переводчиками, главным образом, для реноминации элементов народного языка: пословиц, поговорок, прибауток, частушек, фрагментов народных говоров, отступлений от фонетической и грамматической нормы русского языка как части речевой характеристики персонажа. Как правило, создаваемые уникальные текстовые эквиваленты успешно выполняют те же функции, что и реалии ИТ.

Ср., например:

ИТ: «Как на грех, на беду...» То бишь: «Пел на грех, на беду соловей во саду - песню томную... Глупой спать не давал - в ночку темную...»

ПТ1: Comme pour mon malheur... Non, voilà. Il chantait pour mon malheur, Le rossignol dans les fleurs, Sa chansonnette langoureuse... Troublait la sotte en son sommeil - Par cette nuit tènébreuse... [11, p. 164].

ПТ2: «Par malheur, par chagrin...»C'est ça : "Oh malheur, oh péchè, le rossignol au jardin chantait -sa chanson d'amour... Et la sotte l'écoutait - jusqu'au petit jour...» [12, p. 35].

В обоих ПТ при передаче фрагмента песни переводчикам удается как сохранить денотативный компонент, так и воссоздать образность ИТ благодаря рифме.

Для С-реалий, обозначающих обычаи и традиции русской культуры, используются свои С-реалии, созданные посредством дословного перевода:

ИТ: (...) с Герваськой он крестами менялся...

ПТ1: (...) en signe d'amitié fraternelle, il fit un échange de croix avec Guérassim [11, p. 148].

ПТ2: (...) avec Guervaska il avait échangé sa croix... [12, p. 14].

В данном примере дословный перевод используется в ПТ2, тогда как в ПТ1 присутствует переводческое добавление, делающее смысл С-реалии более понятным иноязычному читателю: в знак братской дружбы он поменялся крестами. Такой вариант перевода следует признать более удачным, поскольку позволяет избежать возникновение в ПТ лакуны.

Чужая С-реалия может реноминироваться в ПТ путем дословного перевода, если переводчик считает фрагмент ИТ понятным для целевой аудитории. Например:

ИТ: И несколько дней, пока не хватились зеркальца, прожила ошеломленная своим преступлением, очарованная своей страшной тайной и сокровищем, как в сказке об аленьком цветочке.

ПТ1: Et durant plusieurs jours, avant qu'on ne s'aperçût du larcin, elle vécut dans la stupeur de son crime, dans l'enchantement de son terrible secret et du presque fabuleux trésor qu'elle détenait [11, p. 179]. 
ПТ2: Pendant quelquesjours, tantqu'on ne remit pas la main sur le miroir, ellefutabasourdie par son méfait, enchantée par son terrible secret et par son trésor, comme dans le conte de la petite fleur rouge [12, p. 55].

В ИТ русская С-реалия - интертекстуальное включение аленький цъветочек отсылает к одноименной сказке С. Т. Аксакова и призвана подчеркнуть силу любви Натальи к барчуку. В ПТ1 М. Парижанин опускает реалию, эксплицируя релевантные компоненты смысла в тексте: почти сказочное сокровище. В ПТ2 «своя» С-реалия воссоздается посредством дословного перевода. В данном случае фрагмент может быть понятен франкоязычному читателю, поскольку «Сказка об аленьком цветочке» - одна из вариаций истории о красавице и чудовище, распространенной в европейских странах.

Однако дословный перевод редко оказывается удачным переводческим решением, поскольку, сохраняя форму, не позволяет носителю другой культуры извлечь информацию, актуализированную С-реалией. Например:

ИТ: Господа за Можай ее загнали бы!

ПТ1: Nos maîtres lui en auraient fait voir de toutes les couleurs !... [11, p. 145].

ПТ2: Les maîtres l'auraient renvoyée de l'autre côté de Mojaï! [11, p. 9].

В приведенном примере И. А. Бунин включает в речь Натальи фразеологизм загнать за Можай, который обозначает загнать очень далеко. История появления данного выражения подробно описана в [27] и связана с защитой Москвы от поляков К. Мининым и Д. Пожарским в 1611 г. В ПТ2 фразеологизм передается при помощи простого перекодирования: отправили бы по другую сторону Можая. Данный способ реноминации не позволяет верно интерпретировать контекст, поскольку франкоязычный читатель (как, впрочем, сегодня и многие русскоязычные) вряд ли знаком с ролью г. Можайск в истории России. В ПТ1 М. Парижанин использует функциональный эквивалент: en faire voir de toutes les couleurs - разг. подвергнуть кого-либо различного рода испытаниям и неприятностям.

Чаще всего наиболее полно культурно-специфичные смыслы при сохранении исходной формы «чужой» C-реалии удается передать посредством модели реноминации «Чужая C-реалия - Чужая L-реалия + Своя С-реалия», где «своя» С-реалия представлена переводческим метатекстом. К примеру:

ИТ: быстро исчезали на наших глазах и гнезда суходольские.

ПТ1: ainsitombaientrapidement, à nosyeux, les nids de Soukhodol [11, p. 232].

ПТ2: disparaissaientaussicomplètement et aussirapidement sous nosyeux les nids de gentilshommes* comme celui de Soukhodol [12, p. 133].
*Titre d'un roman de Tourgueniev paru en 1859.

В анализируемом примере И. А. Бунин использует аллюзию на роман И. С. Тургенева «Дворянское гнездо», употребляя множественное число и проводя параллель между Суходолом и упадком других дворянских усадеб с целью акцентировать важнейшую роль усадьбы в становлении и жизни ее обитателей. В ПТ1 переводчик прибегает к дословному переводу, используя «чужую» L-реалию: гнезда Суходола. В ПТ2 «чужая» L-реалия входит в состав своей C-peaлии экспликации (дворянские гнезда как Суходол), которая сопровождается еще одной «своей» С-реалией в переводческом метатексте. Безусловно, смысл контекста будет понятен франкоязычному читателю лишь в том случае, если он знаком с содержанием произведения И. С. Тургенева. Однако интертекстуальную отсылку такой способ реноминации в ПТ воссоздает успешно.

В некоторых случаях сложный характер культурно-специфичных сведений, актуализируемых C-peaлиями, побуждает переводчиков использовать комплексные способы реноминации. Например:

ИТ: Не сама ли это Баба Яга?

ПТ1: N'était-cepas, enpersonne, la fameuse BabaYaga, l'Ogresse, - songions-nous (...) [11, p. 152].

ПТ2: On aurait dit Baba-Iaga* [12, p. 20].

*Sorcière des contes populaires russes.

В анализируемом примере используется русская C-реалия, обозначающая одного из самых известных персонажей русских сказок. В ПТ1 реноминация осуществляется по модели «чужая L-реалия + Своя C-реалия», где своя С-реалия представлена функциональным эквивалентом Ogresse - людоедка. В ПТ2 реноминация происходит по той же модели, однако своя С-реалия представлена переводческим комментарием. В обоих ПТ, таким образом, актуализируются хотя и разные, но достаточные для понимания контекста черты реалии.

Наконец, С-реалии в ПТ могут опускаться при условии экспликации компонентов их смысла непосредственно в тексте перевода. Например:

ИТ: хохлуика подколодная! - крикнула раз одна из подруг ее по девичьей.

ПТ1: O la vilaine cachottière! [11, p. 203].

ПТ2: Ouh, qu'elle est rusée, l'Ukrainienne! [12, p. 89].

В ИТ используется словосочетание хохлушка подколодная, которое можно рассматривать как С-реалию, поскольку для его понимания необходима активизация целого комплекса культурно-специфичных сведений. Так, слово хохлушка имеет в словарях помету «разг.» [23] и может использоваться с пейоративным оттенком. Прилагательное подколодная апеллирует к русским народным сказкам, где в сочетании с существительным змея обозначает коварного и злого чело- 
века. В обоих ПТ переводчики не передают смысл C-реалии, но сохраняют отрицательную коннотацию: ПТ1 - la vilaine cachotière - гнусная скрытница; ПТ2 - qu'elle est rusée, l'Ukrainienne! - Какая же она хитрая, эта украинка!

Проведенный анализ способов реноминации реалий, образующих художественный реаликон повести «Суходол», позволяет говорить о кардинальных изменениях его структуры в процессе перевода.

По сравнению с ИТ в ПТ отмечаются, прежде всего, количественные изменения.

Количественный анализ способов реноминациии дал следующие результаты (табл. 1).

$$
\text { Т а б ли ц а } 1
$$

Cпособы реноминации $R$-реалий

\begin{tabular}{|l|c|c|}
\hline \multicolumn{1}{|c|}{ Способ реноминации } & ПТ1 & ПТ2 \\
\hline чужая L-реалия & $57(23 \%)$ & $56(23 \%)$ \\
\hline $\begin{array}{l}\text { чужая L-реалия + своя С-реалия } \\
\text { переводческий метатекст) }\end{array}$ & $4(2 \%)$ & $11(4 \%)$ \\
\hline $\begin{array}{l}\text { своя R-реалия (функциональный } \\
\text { эквивалент) }\end{array}$ & $59(23 \%)$ & $62(26 \%)$ \\
\hline своя R-реалия (гипероним) & $63(26 \%)$ & $61(25 \%)$ \\
\hline $\begin{array}{l}\text { своя С-реалия (развернутая } \\
\text { номинация) }\end{array}$ & $51(21 \%)$ & $33(14 \%)$ \\
\hline опущение & $16(6 \%)$ & $19(8 \%)$ \\
\hline
\end{tabular}

Сравнение приведенных выше данных позволяет сделать следующие выводы.

1. Доля опущения реалий в ПТ в сравнении с другими типами реноминации мала (6-8 \%), что свидетельствует о стремлении переводчиков сохранить реалию ИТ как важный маркер эстетики бунинского текста.

2. Доля способов реноминации, предусматривающих сохранение «чужих» реалий («чужая» L-реалия и «чужая» L-реалия + «своя» C-реалия) в обоих ПТ приблизительно одинакова: ПТ1 - 25 \%; ПТ2 - 27 \%. Это означает, что только четвертая часть реалий ИТ сохраняется в ПТ в качестве знаков «чужой» (русской) культуры, что связано, с одной стороны, со стремлением переводчиков избежать «перенасыщения» текста чужими реалиями, тем самым усложнив его понимание читателем, а с другой - с неизвестностью большинства традиционных русских реалий во французской культуре и слабой степенью освоенности русской действительности французским языком. Как следствие, освоения не происходит, и о русской действительности французы так и не узнают.

3. «Свои» французские реалии в обоих ПТ оказываются наиболее многочисленными (ПТ1 - 70 \%; ПТ2 - 65 \%). При этом количество реноминаций посредством гиперонима приблизительно одинаково
(26 и $25 \%$ соответственно). В то же время в ПТ1 «освоение» русской действительности средствами французского языка происходит более активно, поскольку более частотными оказываются французские R-реалии - функциональные эквиваленты и C-реалии - экспликации.

Т а бли ц а 2

Способы реноминаичии С-реалий

\begin{tabular}{|l|c|c|}
\hline \multicolumn{1}{|c|}{ Способ реноминации } & ПТ1 & ПТ2 \\
\hline $\begin{array}{l}\text { своя С-реалия - функциональ- } \\
\text { ный эквивалент }\end{array}$ & $21(46 \%)$ & $16(35 \%)$ \\
\hline своя С-реалия - экспликация & $4(9 \%)$ & $3(6 \%)$ \\
\hline $\begin{array}{l}\text { своя С-реалия - дословный } \\
\text { перевод }\end{array}$ & $19(41 \%)$ & $23(50 \%)$ \\
\hline $\begin{array}{l}\text { своя С-реалия - переводческий } \\
\text { метатекст }\end{array}$ & $0(0 \%)$ & $3(7 \%)$ \\
\hline Опущение & $2(4 \%)$ & $1(2 \%)$ \\
\hline
\end{tabular}

Количественный анализ способов реноминации С-реалий (табл. 2) позволяет говорить о практически полной адаптации этого сегмента реаликона ИТ как в ПТ1, так и в ПТ2.

Таким образом, полевая модель реаликона ПТ может быть представлена следующим образом.

В соответствии с критериями частотности употребления в ПТ и полноты и интенсивности национально окрашенных компонентов значения свое место в ядре реаликонов обоих ПТ сохраняют только 2 русские L-реалии изба (isba - ПT1: 19 раз; ПТ2 15 раз) и образ (icône - ПТ1: 7 раз; ПТ2 - 11 раз). В ПТ2 в ядро также входит реалия барчук, реноминация которой осуществляется за счет введения в ПТ «чужой» L-реалии bartchouk, сопровождающейся переводческим комментарием: Petit barine, jeune fils de barine: propriétaire terrien, maître (Маленький барин, молодой сын барина: земельного собственника, хозяина). При этом переводчик подбирает и другие текстовые эквиваленты (реалия bartchouk употребляется 4 раза, fils du maître, monsieur Arkadi - по 1 разу, le jeune maître - 3 раза), что приводит к снижению частотности употребления реалии в сравнении с ИТ.

Несколько дальше от центра ядра реаликона в обоих ПТ отстоят наиболее частотные французские R-реалии, использованные переводчиками для номинации ключевых концептов бунинской эстетики. Так, в ПТ1 реалия усадьба, выполняющая символьную и структурообразующую функцию, сохраняет свою позицию в ядре, поскольку для ее реноминации переводчик выбирает только две «свои» реалии: enclos (7 раз) и manoir (12 раз). Можно утверждать, что такое ограниченное количество текстовых эквивалентов позволяет воссоздать функциональный потенциал 
данной реалии в ПТ. В ПТ2 место в ядре сохраняют французские R-реалии, реноминирующие реалию дворня (domestiques - 13 раз, domesticité - 2 раза).

Наконец, в ядро входят русские L-реалии, для понимания которых французский читатель обращается к «своим» С-реалиям, представленным переводческим метатекстом или словарной дефиницией.

Ближняя периферия реаликонов ПТ сформирована несколькими группами реалий ИТ. Во-первых, место на ближней периферии сохраняют С-реалии, описывающие обычаи и обозначающие интертекстуальные включения, поскольку для их реноминации используются развернутые экспликации или переводческий метатекст. Так, в приведенном выше случае с С-реалией гнезда суходольские она войдет в ближнюю периферию в ПТ2, где присутствуют C-реалии экспликация и метатекст, а в ПТ1, где передается дословным переводом, сместится на дальнюю периферию.

Кроме того, на ближнюю периферию смещаются реалии, символьная функция которых оказалась, повидимому, нераспознана переводчиками: они подобрали целый ряд текстовых эквивалентов, которые представляют собой контекстуальные синонимы. Синонимический ряд можно рассматривать как внутритекстовую экспликацию, каждое слово которой обогащает основную С-реалию. Например, для ПТ1 это реалия дворня, для которой М. Парижанин использовал несколько эквивалентов, тем самым снизив ее частотность в ПТ: domestiques - 2 раза, domesticité2 раза, serviteurs - 4 раза, nos gens - 5 pa3, gens de service, gens de la maison - по одному разу. В ПТ2 на ближнюю периферию перемещается реалия усадьба, поскольку она передается следующими способами: propriété - «имение» (2 раза), domaine - «поместье, имение, владение» (2 раза), maison - «дом» (11 раз), maison des maîtres - «хозяйский дом» (1 раз), Soukhodol - «Суходол» (2 раза), опущение (3 раза). Таким образом, в ПТ2 происходит некоторое смещение семантической доминанты и значение «русской» реалии усадьба как символа в ПТ «размывается», реалия выполняет символьную функцию менее успешно. Однако использование такого синонимического ряда позволяет переводчику избежать повтора, который во французском тексте традиционно считается стилистической ошибкой.

Наконец, в ПТ1 на ближней периферии оказываются и некоторые французские R- и C-реалии, которые сопровождаются поясняющим комментарием переводчика: М. Парижанин делится с читателем логикой принятия переводческих решений, описывая «чужую» реалию и поясняя выбор эквивалента. Например:

ИТ: Она была в плахте и вынитой сорочке, хотя покрыта темным платочком по-нашему (...)
В комментарии читаем: Наталья теперь одета в малоросский костюм: плахта - это одежда, напоминающая в некотором роде футляр, который обтягивает грудь, талию и ноги; она обычно изготавливается из ткани в полоску или клетку ярких цветов. Mbl переводим «нижняя юбка» в силу отсутствия более удачного эквивалента.

Дальняя периферия реаликонов ПТ включает наибольшее число компонентов, сформирована наименее частотными «своими» R-реалиями, представляющими собой функциональные эквиваленты или гиперонимы, поскольку они лишены русского национального колорита. Таким образом, на периферию реаликонов ПТ смещаются как реалии с общенациональным компонентом значения, так и с региональным: пунька - в ПТ1 l'appentis [11, р. 151], в ПТ2 les granges [12, p. 17].

Кроме того, дальняя периферия также включает русские R-реалии, которые переданы посредством «своей» C-реалии-экспликации, так как данный способ реноминации позволяет восстановить некоторые национально окрашенные компоненты значения с использованием средств исключительно французского языка, зачастую на основе R-реалии - функционального эквивалента: ПТ1: apanник - long fouet, шестая книга (дворянства) - le plus ancien des nobiliaires, лапти - chaussons de teille, суздальское изображение безглавого человека-naїve représentation dи таrtyr, службы и людские в несколько связей-dеих longues suites de communs et d'isbas domestique, журавль колодиза-une chèvre à bascule sur le puits и др.

ПТ2: сахарные сушки - des petits gâteaux secs, службы и людские в несколько связей-des comтипs très longs et les maisons des domestiques, иинель - таnteau à capuche).

На дальней периферии оказываются C-реалии, реноминируемые посредством дословного перевода, а также С-реалии, передающие особенности крестьянской речи. Независимо от выбора стратегии нейтрализации или стилистической компенсации комплекс культурных смыслов в таких случаях неизбежно утрачивается, поскольку в обоих случаях используются ресурсы разных уровней системы французского языка. По этому же принципу на дальнюю периферию реаликонов ПТ перемещаются «свои» С-реалии - функциональные эквиваленты, которые воспроизводят стихотворную форму, и содержание народных песен, пословиц, прибауток, но достигается это средствами французского языка.

Проведенный анализ позволяет сделать вывод, что структура художественного реаликона при переводе существенно меняется. В ПТ в наименьшей степени сохраняется ядро реаликона, передающее наиболее окрашенный сегмент языковой картины мира, отображающий в ИТ традиционную русскую 
действительность. Русские реалии, в том числе и те, которые зафиксированы двуязычными русско-французскими и французско-русскими словарями, в ПТ употребляются крайне редко: когда реалия воспринимается как маркер русской культуры для французского читателя, даже если ее значение не удается полностью восстановить на основе контекста. Недостаточная известность русских реалий и слабая степень их освоенности французским языком делает предпочтительным ПТ с использованием «своих» реалий. Таком образом, в ядре художественного реаликона ПТ оказываются наиболее частотные французские R-реалии, реноминирующие ключевые русские реалии с их символьной функцией. Эти компоненты ядра ПТ крайне малочисленны в сравнении с объемом ядра ИТ, а их включение в ядро зависит от того, насколько верно переводчик оценил функциональный потенциал компонентов реаликона ИТ. Несколько дальше от ядра реаликона отстоят развернутые номинации, которые создаются переводчиком для передачи релевантных характеристик реалии. Региональные же реалии и подавляющее большинство общенациональных реалий, которые составляют ядро реаликона ПТ (вследствие частотности своего употребления в тексте, ярко выраженной национальной окрашенности и функциональной значимости), передаются в ПТ преимущественно гиперонимами и оказываются на дальней периферии художественного реаликона ПТ или вообще в нем не отражаются. При этом национальный колорит текста «затушевывается», а в некоторых случаях и полностью стирается. В отношении С-реалий исследование позволило выявить схожие закономерности. На ближней периферии находятся «свои» С-реалии - текстовые эквиваленты, эксплицирующие релевантные черты «чужого» концепта. Они представлены С-реалиями-экспликациями и С-реалиями - переводческими метатекстами. Дальнюю периферию образуют С-реалии, в процессе реноминации которых национальный колорит ИТ полностью утрачивается. В повести «Суходол» такими реалиями оказываются элементы фольклора в тексте ИТ, а также С-реалии, переданные посредством дословного перевода.

Отбор способов реноминации реалий при переводе носит регулярный характер, что подтверждает системную организацию художественного реаликона. Задача воссоздания его функций наиболее успешно решается в рамках стратегии лингвокультурной адаптации текста, которая предусматривает комплексное использование моделей реноминации, содержащих «чужие» L- и «свои» C-реалии (в том числе метатекстовые экспликации), а также «свои» R- и C-реалии, представляющие собой текстовые эквиваленты: они создаются переводчиком специально для данного контекста и эксплицируют релевантные характерис- тики реалии средствами «своего» языка. Такое сочетание позволяет наиболее полно воссоздать функциональный потенциал реаликона конкретного произведения в рамках его эстетики. Напротив, преимущественное использование в ПТ «своих» реалий приводит к нейтрализации художественного реаликона и не всегда верной передаче авторской интенции, что напрямую влияет на достижение импрессивной эквивалентности текста перевода.

Анализ способов реноминации реалий, таким образом, позволяет, с одной стороны, выявить сходства и различия в реаликонах как фрагментах картин мира (чужой в ИТ / своей в ПТ), а с другой - определить и обосновать количественно и качественно доминирующую стратегию передачи национального колорита (сохранение/адаптация).

\section{ЛИТЕРАТУРА}

1. Strakhovsky L. La littérature russe contemporaine //

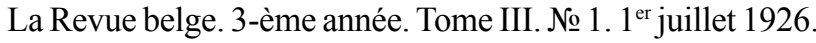
Pp. 65-74.

2. Ledré Ch. Trois romanciers russes: I. Bounine, A. Kouprine, M. Aldanov. Paris : Nouvelles éditions latines, 1935. $158 \mathrm{p}$.

3. Hauchard C. La prose de I. A. Bunin de 1920 a 1953 : la reconstruction d'une œuvre. Thèse de doctorat d'études slaves. Paris : Université Paris-Sorbonne, Paris IV, 1993. $407 \mathrm{p}$.

4. Makine A. La prose de I. A. Bounine. La poétique de la nostalgie. Thèse de doctorat d'études slaves. Paris : Université Paris-Sorbonne, Paris IV, 1992. 570 p.

5. Hauchard C. Préface // I. Bounine. Pommes Antonov. Nouvelles, traduit du russe, préfacй et annotй par Claire Hauchard. Paris : Edition des Syrtes, 2001. Pp. 7-15.

6. Scheidhauer M.-L. Tchekhov, Bounine, Makine, chantres de la terre russe // Andreï Makine, le sentiment poétique. Textes réunis par Margaret Parry, Claude Herly, Marie-Louise Scheidhauer. Paris : L'Harmattan, 2008. Pp. 43-54.

7. Israël F. La trace du lien en traduction // Identité, altérité, équivalence? : La traduction comme relation. Paris, 2002. Pp. 83-91.

8. Parijanine M. Avant-propos // I. Bounine. A la source des jours. Traduit du russe avec un Avant-Propos par Maurice-Parijanine. Librairie Stock, Paris, 1935. Pp. IVI.

9. Кретов А. А., Фененко Н. А. Реноминация как проблема переводоведения // Вестник Воронеж. гос. ун-та. Сер.: Лингвистика и межкультурная коммуникация. 2011. № 2. С. 154-158.

10. Кретов А. А., Фененко Н. А. Лингвистическая теория реалии // Вестник Воронеж. гос. ун-та. Сер.: Лингвистика и межкультурная коммуникация. 2013. № 1. C. 7-13.

11. Bounine I. Le Calice de vie // I. Bounine, traduit du russe par Maurice. Paris : Gallimard, 1990. 252 p. 
12. Bounine I. Soukhodol // I. Bounine, traduit du russe par M. Lejeune; postface d'Olivier Apert. Paris : Édition des Syrtes, 2005. 153 p.

13. Фененко Н. А., Бурякова С. Ю. Индивидуальноавторский реаликон в тексте оригинала и перевода // Язык и действительность. Научные чтения на кафедре романских языков им. В. Г. Гака : сб. ст. по итогам III Междунар. конф. М. : Спутник+, 2018. С. 388-394.

14. Курносова И. М. Лексико-фразеологическая система языка писателей Центрального Черноземья и ее лексикографическая представленность : автореф. дис. ... д-ра филол. наук. Елец, 2009. 49 с.

15. Фененко Н. А. Авторский реаликон Н. В. Гоголя сквозь призму перевода // Новые технологии в обучении переводу в сфере профессиональной коммуникации. М., 2008. C. $435-443$.

16. Косиченко Е. Ф. Лингвосемиотическая концепция ономастикона (на материале художественных текстов) : автореф. дис. ... д-р филол. наук. М., 2017. 48 с.

17. Лингвистический энциклопедический словарь / гл. ред. В. Н. Ярцева. М. : Сов. энциклопедия, 1990. 685 с.

18. Адмони В. Г. Грамматический строй как система построения и общая теория грамматики. Л. : Наука : Ленингр. отд-ние, 1988. 238 с.

19. Суралева Е. Н. Использование методов когнитивного моделирования в исследовании этнокультурных концептов (на примере концепта mobilität) // Вестник Воронеж. гос. ун-та. Сер.: Лингвистика и межкультурная коммуникация. 2013. № 2. С. 65-71.

20. Попова Г. Е. Релевантность речевой интеракции : аспектуальная и жанровая типология : монография / под ред. А. В. Алферова. Пятигорск : Изд-во ПГУ, 2019. $373 \mathrm{c.}$

21. Современный толковый словарь русского языка / под ред. Т. Ф. Ефремовой. URL: https://dic.academic. $\mathrm{ru} /$ contents.nsf/efremova/

22. Larousse. Dictionnaire de français. URL: https:// www.larousse.fr/dictionnaires/francais/cafetan/12094

23. Fol-en-Christ. Wikipédia. Encyclopédie libre. URL: https://fr.m.wikipedia.org/wiki/Fol-en-Christ

24. Российское дворянство. Википедия. URL: https:// ru.m.wikipedia.org/wiki/Российское_дворянство

25. Справочник по фразеологии. URL: https://frazeolog_ru.academic.ru/153/загнать_за_Можай

\section{REFERENCES}

1. Strakhovsky L. La littérature russe contemporaine [Contemporary Russian Litterature]. In La Revue belge. 3-ème année. Tome III. № 1. 1er juillet 1926. Pp. 65-74.

2. Ledré Ch. Trois romanciers russes: I. Bounine, A. Kouprine, M. Aldanov [The Three Russian novelists: I. Bounine, A. Kouprine, M. Aldanov]. Paris: Nouvelles éditions latines, 1935.

3. Hauchard C. La prose de I. A. Bunin de 1920 à 1953: la reconstruction d'une auvre [Prose by I. A. Bunin: the reconstruction of an oeuvre]. Thèse de doctorat d'études slaves. Paris: Université Paris-Sorbonne, Paris IV, 1993. $407 \mathrm{p}$.
4. Makine A. La prose de I. A. Bounine. La poétique de la nostalgie [Prose by I. A. Bunin. Portics of nostalgia]. Thèse de doctorat d'études slaves. Paris: Université ParisSorbonne, Paris IV, 1992.

5. Hauchard C. Préface [Preface]. In I. Bounine. Pommes Antonov. Nouvelles, traduit du russe, préfacé et annoté par Claire Hauchard. Paris: Edition des Syrtes, 2001. Pp. 7-15.

6. Scheidhauer M.-L. Tchekhov, Bounine, Makine, chantres de la terre russe [Tchekhov, Bounine, Makine, the eulogists of the Russian land]. In Andrei Makine, le sentiment poétique. Textes réunis par Margaret Parry, Claude Herly, Marie-Louise Scheidhauer. Paris: L'Harmattan, 2008. Pp. 43-54.

7. Israël F. La trace du lien en traduction [The trace of the link in translation]. In Identité, altérité, équivalence?: La traduction comme relation. Paris, 2002. Pp. 83-91.

8. Parijanine M. Avant-propos [Foreword]. In I. Bounine. A la source des jours. Traduit du russe avec un Avant-Propos par Maurice-Parijanine. Librairie Stock, Paris, 1935. Pp. IVI.

9. Kretov A. A., Fenenko N. A. Renominacija kak problema perevodovedenija [Renomination as a problem of the theory of translation]. In Vestnik Voronezhskogo gosudarstvennogo universiteta. Serija Lingvistika i mezhkul'turnaja kommunikacija. 2011. Issue 2. Pp. 154-158.

10. Kretov A. A., Fenenko N. A. Lingvisticheskaja teorija realii [Lunguistic theory of realia]. In Vestnik Voronezhskogo gosudarstvennogo universiteta. Serija: Lingvistika i mezhkul turnaja kommunikacija. 2013. Issue 1. Pp. 7-13.

11. Bounine I. Le Calice de vie [The Chalice of life]. Traduit du russe par Maurice. Paris: Gallimard, 1990.

12. Bounine I. Soukhodol [Dry Valley]. Traduit du russe par M. Lejeune; postface d'Olivier Apert. Paris: Édition des Syrtes, 2005.

13. Fenenko N. A., Burjakova S. Ju. Individual'no-avtorskij realikon $\mathrm{v}$ tekste originala i perevoda [Realicon of an aithor in the source and the translation texts. In Jazyk $i$ dejstvitel'nost'. Nauchnye chtenija na kafedre romanskih jazykov im. V. G. Gaka. Sbornik statej po itogam III-j mezhdunarodnoj konferencii. Moscow: Sputnik+, 2018. Pp. 388-394.

14. Kurnosova I. M. Leksiko-frazeologicheskaja sistema jazyka pisatelej Central 'nogo Chernozem 'ja i ee leksikograficheskaja predstavlennost' [Lexical and phraseological system of language of the writers of the Black Earth region and its presence in the dictionaries]: avtoref. dis. ... dokt. filol. nauk. Elec, 2009.

15. Fenenko N. A. Avtorskij realikon N. V. Gogolja skvoz' prizmu perevoda [Author's realicon of N. V. Gogol through the lense of translation] // Novye tehnologii v obuchenii perevodu v sfere professional'noj kommunikacii. Moscow, 2008. Pp. 435-443.

16. Kosichenko E. F. Lingvosemioticheskaja koncepcija onomastikona (na materiale hudozhestvennyh tekstov) [Lingvosemiotic conception of onomasticon: based on fiction texts]: avtoref. dis. ... dokt. filol. nauk. Moscow, 2017. 
17. Lingvisticheskij jenciklopedicheskij slovar' [Lingustic encyclopedic dictionary] / gl. red. V. N. Jarceva. Moscow: Sovetskaja jenciklopedija, 1990.

18. Admoni V. G. Grammaticheskij stroj kak sistema postroenija i obshhaja teorija grammatiki [Grammar system as a system of construction and general theory of grammar]. Leningrad: Nauka: Leningr. otd-nie, 1988.

19. Suraleva E. N. Ispol'zovanie metodov kognitivnogo modelirovanija $\mathrm{v}$ issledovanii jetnokul'turnyh konceptov (na primere koncepta mobilität) [The use of cognitive modeling methods in the study of ethnocultural concepts (based on the example of the concept "mobilität")]. In Vestnik VGU. Serija Lingvistika i mezhkul'turnaja kommunikacija. 2013. Issue 2. Pp. 65-71.

20. Popova G. E. Relevantnost' rechevoj interakcii: aspektual'naja i zhanrovaja tipologija [Relevance of speech interaction: aspectual and genre typology]. Monografija. Pod red. A. V. Alferova. Pjatigorsk: Izd-vo PGU, 2019.

\section{Воронежский государственный университет}

Фененко Н. А., доктор филологических наук, профессор кафедры франиузской филологии

E-mail:fenenko@rgph.vsu.ru

Бурякова С. Ю., кандидат филологических наук, доиент кафедры франиузской филологии

E-mail: bulgakova@rgph.vsu.ru

Поступила в редакциию 19 февраля 2020 г.

Принята к публикации 25 марта 2020 г.

\section{Для цитирования:}

Фененко Н. А., Бурякова С. Ю. Художественный реаликон как категория переводоведения // Вестник Воронежского государственного университета. Серия: Лингвистика и межкультурная коммуникация. 2020. № 2. C. 39-50. DOI: https://doi.org/10.17308/lic.2020.2/2836
21. Sovremennyj tolkovyj slovar' russkogo jazyka [Modern explanatory dictionary of the Russian language]. Pod red. T. F. Efremovoj. Available at: https://dic.academic.ru/ contents.nsf/efremova/

22. Larousse. Dictionnaire de français [Larousse. French language dictionary]. Available at: https://www. larousse.fr/dictionnaires/francais/cafetan/12094

23. Fol-en-Christ [Foolishness for Christ] // Wikipédia. Encyclopédie libre. Available at: https://fr.m.wikipedia. org/wiki/Fol-en-Christ

24. Rossijskoe dvorjanstvo [Russian nobility] // Wikipedija. Available at: https://ru.m.wikipedia.org/wiki/Rossijskoe dvorjanstvo

25. Spravochnik po frazeologii [Reference book on phraseology]. Available at: https://frazeolog_ru.academic. ru/153/zagnat'za_Mozhaj

Voronezh State University

Fenenko N. A., Doctor of Philology, Professor of the French Philology Department

E-mail:fenenko@rgph.vsu.ru

Buryakova S. Yu., Candidate of Philology, Associate Professor of the French Philology Department

E-mail:bulgakova@rgph.vsu.ru

Received: 12 February 2020

Accepted: 25 March 2020

\section{For citation:}

Fenenko N. A., Buryakova S. Yu. Artistic realikon as a category of translation studies. Proceedings of Voronezh State University. Series: Linguistics and Intercultural Communication. 2020. No. 2. Pp. 39-50. DOI: https://doi. org/10.17308/lic.2020.2/2836 